\title{
Zastosowania memetyki w dydaktyce. Recenzja książki Marka Kaczmarzyka Szkoła memów. W stronę dydaktyki ewolucyjnej
}

Marek Kaczmarzyk, Szkota memów. W strone dydaktyki ewolucyjnej, Gliwice 2018.

„Teksty z Ulicy. Zeszyt memetyczny” 2019, nr 20

Https://doi.org/10.31261/tzu.2019.20.09

Z wielką ciekawością przystąpiłem do lektury nowej książki Marka Kaczmarzyka Szkota memów. W strone dydaktyki ewolucyjnej. Po pierwsze, podobnie jak jej autor uważam, że obecna polska szkoła ma wiele wad, przy czym większość z nich jesteśmy w stanie wyeliminować, ponadto zachodzi potrzeba uświadamiania nauczycieli w zakresie odkryć współczesnej psychologii i neuronauk, pozwalających na usprawnienie procesu dydaktycznego. Po drugie, od dłuższego czasu jestem pod wrażeniem dokonań autora, który wywodząc się z nauk biologicznych, poświęca wiele uwagi zarówno popularyzacji swojej dyscypliny naukowej ${ }^{1}$, jak i wypracowywaniu bardziej efektywnych metod nauczania w ramach neurodydaktyki ${ }^{2}$. Dlatego też zaraz po ukazaniu się książki zabrałem się do lektury, po czym, uznawszy, że książka warta jest polecenia, przygotowałem jej recenzję. Ta jednak ukazuje się z pewnym opóźnieniem, ponieważ nie udało się jej zmieścić w cyklu wydawniczym poprzedniego numeru „Tekstów z Ulicy”. Mam nadzieję, że niniejszy tekst przyczyni się do popularyzacji wartościowej książki jaką jest Szkota memów.

Książka Marka Kaczmarzyka jest zbiorem tekstów, z których większość ukazała się jako samodzielne artykuły ${ }^{3}$. Zostały one jednak tak ułożone, że sprawiają wrażenie przemyślanej całości skoncentrowanej wokół projektu dydaktyki ewolucyjnej. Co prawda, z tego względu w kolejnych rozdziałach książki znajdziemy powtórzenia, lecz nie jest to mankamentem. Powtórzeń nie jest bowiem zbyt wiele, powtarzający się wątek często jest rozszerzony lub ujęty w nieco innym aspekcie, a także - co istotne - jest to świadomy zabieg autorski.

${ }^{1}$ Oczywiście nie jest w tym jedyny, vide Richard Dawkins.

2 Neurodydaktykę można rozumieć jako dziedzinę inspirowaną odkryciami nauronauk i psychologii zajmująca się usprawnianiem procesu dydaktycznego. Sam Kaczmarzyk o niej pisze w recenzowanej książce: M. Kaczmarzyk, Szkota memów. W stronę dydaktyki ewolucyjnej, Gliwice 2018, s. 46.

${ }^{3}$ Tamże, s. 21. 
Postanowiłem pozostawić te fragmenty [tj. fragmenty, które się powtarzają - przyp. A.S.] z dwóch powodów. Po pierwsze dlatego, że niemal każdy rozdział można dzięki temu traktować jako odrębną całość, która nie wymaga zasadniczo czytania poprzednich. Po drugie, wiele zjawisk spotykanych w szkole, które wydają się z pozoru różne, ma z przyjętej tu perspektywy podobne przyczyny albo można je wyjaśniać w podobny sposób. Dzięki temu model, który budujemy, staje się stopniowo pełniejszy, choć oczywiście nie przestaje być jedynie modelem4

W tym miejscu warto odnieść się do głównego spoiwa książki, na gruncie którego buduje Kaczmarzyk swój model szkoły i edukacji, czyli do dydaktyki ewolucyjnej. Bazuje ona na założeniu, że „ogólny mechanizm zmian przystosowawczych (ewolucyjnych) jest podobny na każdym poziomie, na jakim istnieja obiekty zdolne do samodzielnej reprodukcji”. Autor koncentruje się na dwóch płaszczyznach dziedziczenia: (a) biologicznej, na której dochodzi do transferu informacji genetycznej; oraz (b) kulturowej, gdzie mamy do czynienia z przekazywaniem memów i ich zbiorów (mempleksów). Głównym mechanizmem, do którego odwołuje się dydaktyka ewolucyjna, jest dobór naturalny ${ }^{6}$, nie pomija się jednak innych mechanizmów, takich jak dobór sztuczny czy dobór płciowy.

Istotą naszego opisu - precyzuje Kaczmarzyk - jest przyjęcie ewolucyjnej perspektywy, ponieważ proces ewolucji, rozumiany jako zmiana przystosowawcza, ma miejsce wszędzie tam, gdzie równocześnie zachodzą trzy zjawiska: reprodukcja (powielanie związane z przekazywaniem cech), zmienność (występowanie różnorodności) i selekcja, która określa rodzaj zmian w czasie ${ }^{7}$.

Dzięki uwzględnieniu procesów ewolucyjnych i ich rezultatów, Kaczmarzyk jest w stanie przekonująco wyjaśnić m.in. powszechność ściągania w szkole ${ }^{8}$.

Przyjęcie paradygmatu ewolucyjnego pozwala także na przerzucenie mostów między naukami biologicznymi a naukami społecznymi i humanistycznymi. Jak pisze Kaczmarzyk: „Dydaktyka ewolucyjna łączy takie dziedziny wiedzy, jak neurobiologia i fizjologia procesów uczenia się i nauczania z jednej strony oraz me-

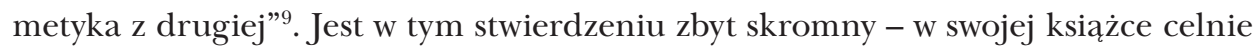
i interesująco nawiązuje do rezultatów zarówno nauk biologicznych, z których jako badacz się wywodzi, jak i psychologii, pedagogiki, filozofii ${ }^{10}$, czy nauk o kulturze, w tym również memetyki. Tej ostatniej poświęca wiele miejsca, widząc w niej teoretyczny fundament proponowanego ujęcia szkoły i źródło praktycznych wskazań dla dydaktyków. Szkoła w ujęciu Kaczmarzyka jest „subśrodowiskiem społecznym,

4 Tamże, s. 21.

5 Tamże, s. 25.

6 Tamże, s. 25-26.

7 Tamże, s. 30.

8 Tamże, s. 91-95.

9 Tamże, s. 26.

${ }^{10}$ Tu miałbym drobne zastrzeżenie: fragment na stronie 35 Szkoty memów sugeruje, że obiekty Popperowskiego świata trzeciego dadzą się sprowadzić do obiektów należących do świata drugiego. 
którego zadaniem jest wybór i wspieranie potencjalnie użytecznych memów i ich zbiorów”11, „zróżnicowanym i bogatym środowiskiem społecznym, które przed tworzącymi je jednostkami stawia wciąż nowe zadania, zmienia się, odpowiada na wyzwania świata zewnętrznego, czasem je podejmując, a czasem negując"12. Z drugiej strony, istnieje też mempleks szkoły, czyli zbiór memów określających zadania szkoły i jej cechy. Niestety mempleks ten - przynajmniej w obecnym kształcie - powoduje zasklepienie się szkoły wokół działań dydaktycznych, które nie przyczyniają się do nabywania przez uczniów przydatnych we współczesnym świecie kompetencji. Próby radykalnej modyfikacji mempleksu szkoły jak na razie nie przynoszą sukcesu z racji tego, że ów mempleks skutecznie infekuje umysły kolejnych generacji, a jego zamknięta struktura jest odporna na zmiany ${ }^{13}$.

Mempleks szkolny jest tym czym w nauce staje się paradygmat. Jest osią działania, stabilnym zbiorem memów „twardych”, które zapewniają trwanie i ograniczają zmiany. Mempleks takiej szkoły jest dzisiaj zbiorem szczególnie zaraźliwych wirusów umysłu. Tyle że infekcja, o której tu mówimy, to coś więcej niż zwykły katar¹4.

Autor porównuje działanie obecnej szkoły do doboru sztucznego, gdzie hodowca decyduje o tym, jakie cechy zostaja przekazane młodym pokoleniom: szkoła arbitralnie wybiera mempleksy, które uważa za użyteczne, a następnie nagradza za ich przyswojenie, a każe za ich nieznajomość. Jednakże w szybko zmieniającym się środowisku, jakim jest współczesny świat, odgórnie wybrane mempleksy mogą okazać się mało użyteczne, a standaryzacja i unifikacja programów nauczania gorzej przygotowuje do współczesnych wyzwań niż postawienie na memetyczną różnorodnośćc ${ }^{15}$.

Kaczmarzyk jednak się nie poddaje, w wielu miejscach książki postulując zmiany, mające poprawić funkcjonowanie szkoły. Możemy podzielić je na zalecenia w skali makro i mikro. Do tych pierwszych należy postulat odejścia od standardowych, zunifikowanych, przeładowanych szczegółowymi informacjami z wielu dziedzin programów nauczania na rzecz programów nauczania uwzględniających memetyczną różnorodność, wykształcenie najistotniejszych kompetencji (np. krytycznego podejścia do źródeł, analizy informacji, kreatywności itp.) i zakotwiczających uzyskaną wiedzę w praktyce, a także wskazanie na potrzebę zwiększenia autorytetu nauczyciela i właściwego doboru sposobów dotarcia do uczniów ${ }^{16}$. Z kolei wśród zaleceń w skali mikro, biorących się z uwzględnienia dokonań psychologii i neuronauk, które powinny znaleźć się w warsztacie dydaktycznym każdego nauczyciela, znajdziemy:

- wskazanie na różnice w szybkości przetwarzania informacji między wy-

kładowcą a słuchaczem i związane z tym nieoczywiste dla wielu zalecenie

11 Tamże, s. 21.

12 Tamże, s. 27.

13 Tamże, s. 155-156.

14 Tamże, s. 156.

15 Tamże, s. 165-168.

16 Tamże, s. 141-142. 
zwiększenia tempa mówienia przez wykładowcę, a także podkreślenie roli resetu i przyciągania uwagi słuchaczy ${ }^{17}$;

- ukazanie praktycznych konsekwencji znajomości działania neuronów lustrzanych ${ }^{18}$

-- unaocznienie ogromnej wartości treningu mentalnego, czyli tego, że wyobrażanie sobie wykonania danej czynności pomaga w jej opanowaniu ${ }^{19}$;

- zwrócenie uwagi na rolę emocji w zapamiętywaniu i na większą użyteczność nagród niż kar²0;

- zalecenie dostosowania długości i zawartości informacyjnej komunikatu wykładowcy do ograniczonej pojemności pamięci roboczej słuchaczy ${ }^{21}$;

- uwidocznienie różnic w pracy grupowej w zależności od płci²2.

Warto zwrócić uwagę, że książka napisana jest przystępnym, a jednocześnie precyzyjnym językiem, autor umiejętnie przeplata fragmenty teoretyczne z praktycznymi wskazówkami, a swoje wywody ilustruje konkretnymi przykładami, co sprawia, że Szkote memów po prostu dobrze się czyta. Należy też wspomnieć, że publikacja jest perfekcyjnie zredagowana, korekta sprawiła się wyśmienicie, dzięki czemu nie znajdziemy w niej ani literówek, ani błędów językowych (co, wbrew pozorom, nie jest takie częste nawet w publikacjach wydawanych przez duże wydawnictwa). Jedyny poważny zarzut dotyczy przypisów bibliograficznych. Kaczmarzyk odsyła w nich do tekstów, w tym również pokaźnych pod względem objętości książek, bez podawania numerów stron, na których czytelnik może znaleźć interesujące go informacje. Przykładowo na stronie 77 Szkoty memów znajdujemy frapujące stwierdzenie: „Wyższe językowe kompetencje kobiet i ich skłonność do swobodnej wymiany informacji sprzyjają ewolucji memów i zapewniają ich różnorodność”"2, opatrzone dwoma odnośnikami bibliograficznymi - do książek Dunbara Pchty, plotki i ewolucja jezyka oraz Hrdy Kobieta, której nigdy nie byto - oczywiście bez podania numerów stron. Zainteresowany rozwinięciem i uzasadnieniem tego twierdzenia czytelnik jest zmuszony do przeczytania obu książek, a następnie do wydobycia z nich i porównania fragmentów odnoszących się do przedstawionej tezy. A jeśli w książkach znajdują się - oprócz tych wspierających tezę - fragmenty jej przeczące? Czytelnik ma zatem nie tylko zapoznać się ze wskazanymi publikacjami, ale także dokonać ich dość zaawansowanej analizy, odgadując, o które ich fragmenty chodzi autorowi Szkoty memów. Oczywiście taki

\footnotetext{
17 Tamże, s. 47-49.

18 Tamże, s. 53-54.

19 Tamże, s. 56.

Tamże, s. 59.

1 Tamże, s. 61.

2 Tamże, s. 77-78.

23 Tamże, s. 77.
} 
sposób tworzenia odnośników bibliograficznych nie obciąża tylko Kaczmarzyka - wielu autorów postępuje podobnie. Jest to zresztą bardzo wygodne dla autora, który nie musi mozolnie wypisywać stron, na których znajduje się potwierdzenie jego stanowiska, lecz jedynie ogólnie wskazuje na publikację, w której znajduje się (albo i nie) uzasadnienie jego twierdzeń. Uważam, że do całych publikacji (tj. bez podania konkretnych stron) możemy odwoływać się tylko w wypadku, gdy cały tekst, do którego odsyłamy, jest potwierdzeniem naszego stwierdzenia (częściej jest tak w odniesieniu do artykułów, które są krótsze niż książki i podejmują mniej wątków), ewentualnie gdy dajemy czytelnikowi możliwość pogłębienia tematu, odsyłając go np. do podręczników czy monografii z danego zakresu. Natomiast w przypadku, gdy potwierdzenie naszego stwierdzenia znajduje się we fragmencie tekstu, mamy obowiązek dokładnego wskazania tegoż przez podanie numerów stron. Dbajmy zatem o czytelnika i pamiętajmy o podawaniu numerów stron tekstów, do których się odwołujemy, nie tylko przy cytatach. Gdyby ukazało się kiedyś nowe wydanie Szkoły memów, sugerowałbym uzupełnienie odnośników bibliograficznych o numery stron.

Opisany mankament nie zmienia mojej pozytywnej oceny książki. Szkota memów może być wartościową lekturą dla bardzo wielu. Dla tych, od których zależy charakter polskiej szkoły, czyli dla rządzących, dydaktyków układających programy nauczania, nauczycieli, ale też uczniów i ich rodziców. Dla wszystkich tych, którzy chcą lepiej zrozumieć proces nauczania i podnieść swoje kompetencje w tym zakresie, czyli dla pedagogów, nauczycieli i trenerów, ale także dla rodziców wychowujących swoje dzieci. I wreszcie dla memetyków: książka z jednej strony ukazuje niezwykle istotny obszar zastosowania memetyki (i inżynierii memetycznej), jakim jest dydaktyka, z drugiej zaś zawiera interesujące rozważania ogólnomemetyczne, np. autorskie rozumienie memu ${ }^{24}$. Wymienionym osobom i wszystkim innym - polecam Szkote memów Marka Kaczmarzyka.

24 Tamże, s. 106-107. 